\title{
Utilization of Advanced Simulation Methods for Solving of Assembly Processes Automation Partial Tasks
}

Darina Kumičáková ${ }^{1}$, Filip Górski ${ }^{2}$, Andrzej Milecki², Damian Grajewski ${ }^{2}$

${ }^{1}$ University of Žilina, Faculty of Mechanical Engineering, Department of Automation and Production Systems, Univerzitná 8215/1, 01026 Žilina, Slovakia, darina.kumicakova@ @stroj.uniza.sk

${ }^{2}$ Poznan University of Technology, Piotrowo 3 Str, PL-60-965 Poznan, Poland, filip.gorski@put.poznan.pl, andrzej.milecki@ put.poznan.pl,damian.grajewski@put.poznan.pl

Projecting and designing of automated assembly cells/lines is very complicated process. The rising demand on an assembly high quality, precision, effectiveness and shorter time to market. Puts the high requirements on the all active devices which act at the automated workplace. Assembly robot with its effector influences the effectiveness of the proposed assembly automation very significantly. Design or choice of the assembly robot and its robotic gripper namely is very important step of the automated assembly cells/lines projecting. Secure and stable holding of an assembly object by robotic gripper is one of significant conditions for trouble-less execution of the object automatic implementation into assembly joint. This article presents our experiences with utilization of advanced simulation methods for the specialized robotic gripper grasping ability exploration for purposes to evaluate a safe and stable grasping of different objects. Virtual reality tools - eon reality and haptic device with glove and finger actuators (CyberForce) were applied for simulation experiments realization too.

Keywords: automated assembly, object grasping, simulation model, CAD/CAE systems, virtual reality

\section{Acknowledgement}

This paper was created with support of the national project KEGA 054ŽU-4/2011. The research leading to some of presented results has received funding from the European Community's Research Infrastructure Action - grant agreement VISIONAIR 262044 - under the 7th Framework Program (FP7/2007-2013).

\section{References}

[1] BORST, CH., W., INDUGULA, A., P. (2005). Realistic Virtual Grasping. Proc of the IEEE Virtual reality 2005, 1087-8270/05, pp. 91-98.ISBN: 0-7803-8929-8

[2] ČUBOŇOVÁ, N. (2013). Postprocessing of cl data in CAD/CAM system edgecam using the constructor of postprocessors. In: Journal of Manufacturing Technology, Vol. 13, Issue 2, pp. 158-164. ISSN: 121324894

[3] FUTÓ, J., KREPELKA, F., IVANIČOVÁ, L. (2011). Optimization of rock cutting process using the simulation methods. In: Proceedings of 12th International Carpathian Control Conference, ICCC'2011, Velké Karlovice, Czech Republic, 25 - 28 May 2011, art. no. 5945829, pp. 120-122. ISBN: 978-161284359-9

[4] JAKUBČÍK, M. (2012). Nové trendy v navrhovaní biorobotických chápadiel (New Trends in The Biorobotic Grippers Designing). Dissertation, pp. 145, University of Žilina

[5] KAO, I., LYNCH, K., BURDICK, J. W. (2008). Handbook of Robotics. 27. Contact Modeling and Manipulation, pp.647-669. Springer-Verlag Berlin Heidelberg. ISBN: 978-3-540-23957-4

[6] KOVÁČ, J., SVOBODA, M., LÍŠKA, O. (2000). Automatizovaná a pružná montá̌̌. (Automated and Flexible Assembly), pp. 200. Vienala Košice, ISBN 80-7099-504-1

[7] KUMIČÁKOVÁ, D. (2013). Využitie prostriedkov počítačovej simulácie pri navrhovaní automatizovaných montážnych pracovísk. (Utilisation of the computer simulation tools in automated assembly workplaces designing). In: ATP Journal Plus, 1/2013, pp. 17-19. ISSN: 1336-5010

[8] KUMICAKOVA, D., JAKUBCIK, M. (2013). Specialised Robotic Hand Designing and Object Grasping Simulation. In: Applied Mechanics and Materials, Vol. 282, pp. 90-98. ISSN: 1660-9336

[9] KURIC, I. (2011). New Methods and Trends in Product Development and Process Planning. In: Academic Journal of Manufacturing Technology, Vol. 9, Issue 1, pp. 83-88. ISSN: 1583-7904.

[10] MILLER, A., ALLEN, P. (2004). GraspIt! A Versatile Simulator for Robotic Grasping. IEEE Robotic and Automation Magazine, Vol 11, No. 4, pp. 110-122. ISSN: 1070-9932

[11] PRATTICHIZZO, D., TRINKLE, J. C. (2008). Handbook of Robotics. 28. Grasping, pp.671-700. Springer-Verlag Berlin Heidelberg. ISBN: 978-3-540-23957-4

[12] www.fanuc.co.jp/en/product/catalog/pdf/ROBOGUIDE(E)_v05_s.pdf

[13] www.vida.put.poznan.pl/en/lab_vr 